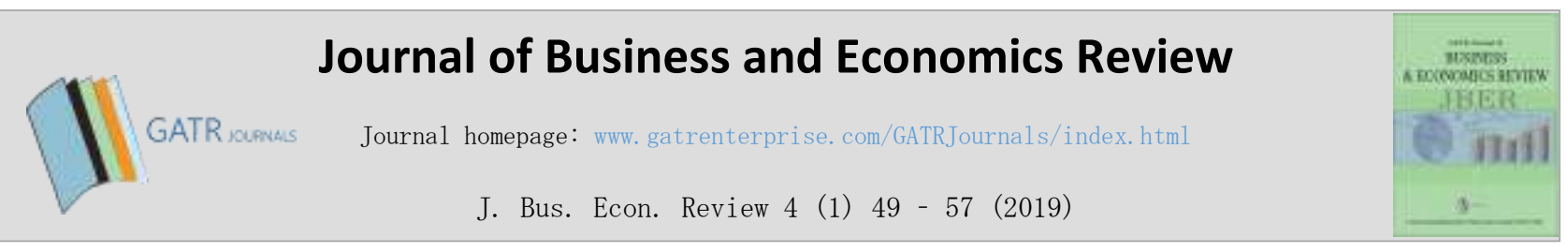

\title{
The Nature of Excessive Behavior (ISRAF) in the Islamic Economic Framework
}

\author{
Zein Muttaqin \\ ${ }^{1}$ Department of Economics, Kulliyah of Economic and Management Sciences, International Islamic University Malaysia, Malaysia.
}

\begin{abstract}
Objective - The objective of this paper is to unfold the nature of excessive behavior in the Islamic economics framework.

Methodology/Technique - This is a library research based on the various studies that specifically discuss excessive behavior and Islamic consumer behavior. The study uses a rating system to identify the relevance of content to the study and analyze content analysis.

Findings - The nature of excessive behavior is condemned by Islam and is fully agreed upon by Muslim scholars. The extent of excessive behavior is not limited to certain levels of consumption. The Muslim consumer may unaware of doing the practice under the influence of a particular setting, where the pleasure of the practice is felt temporarily.

Novelty - This study clarifies the terminology and nature of excessive behavior, which is unclear in previous studies conducted by Muslim scholars.
\end{abstract}

Type of Paper: Review.

JEL Classification: A13, D01, P40, Y80

Keywords: Excessive Behavior; Islamic Economics; Consumer Behavior; Miscellaneous.

\section{Introduction}

The clash between modern economics and Islamic economics is still yet to be resolved, particularly in the field of consumption activity. Nowadays, the issues on consumption are more important for all groups of society. According to Adnan (2011), this is because of the inadequacy of conventional economies to educate the consumer on ethical consumption. The issue to enforce ethics into the consumption framework of a study has become a priority to enhance the efficiency of the economy and social welfare (Azid \& Asutay, 2007). In doing so, the need to enforce exogenous variables such as religion becomes relevant to shape the economy and social structure going forward, so that the agent of economy will behave according to the best normative framework.

\footnotetext{
* Paper Info: Revised: December 16, 2018

Accepted: March 17, 2019

* Corresponding author: Zein Muttaqin

E-mail: zeinmuttaqin@gmail.com

Affiliation: Department of Economics, Kulliyah of Economic and Management Sciences, International Islamic University Malaysia, Malaysia.
} 
The isolation of religion (normative/religious values) from the economy has led to serious problems, particularly inequality issues on a global scale (Khan, 2013). The emergence of Islamic economics as evaluation systems to shape current agent economy and market behavior should be studied comprehensively. However, the development is hampered due to the limitations of comprehensive discussions, especially in the area of consumer behavior. In fact, Kahf (1992) criticizes the fact that there are only a few theorists that have dared to tackle the basic issues in the theory of consumer behavior, including consumer rationalism and the concept of goods. Whereas most of the discussion of Islamic consumer behavior remains limited to discussion of a philosophical stance and philosophical specific features or principles (Adnan, 2011; Furqani, 2017; Hossain, 2014; Khan, 2013; Tahir et. al., 1992).

This study highlights Muslim scholar discussion; the repetitive instrument of Islamic consumer behaviour is to avoid extravagant and luxury indulgence in life. A recent study by Emari (2015) tries to empirically capture and measure the prodigality practice in Muslim lifestyle. He identified two dimensions of prodigality, namely: "social prodigality" and "personal prodigality". Personal prodigality is measured by looking into the personal interest to consume prodigally or self-improvement and for their family improvement at all counts beyond what is needed. Social prodigality is measured by looking from the social interest point of view, meaning the search for social status in the community - which in western studies is categorized as conspicuous consumption or hedonism, etc. However, the term "excessive: (israf) in most of Muslim scholar studies attracts an unclear definition; most scholars translate israf as excessive consumption, prodigally consumption, conspicuous consumption, extravagance, etc. In order to formulate the terminology of israf as is described by the Quran and to put it into practice, the need to understand its nature is necessary. Hence, the objective of this article is to reveal the nature of excessive behavior in the Islamic economic framework. In doing so, we need to derive from the etymological ground to exhibit the nature of israf (excessive) and then discuss its relevance to the theory of consumer behaviour in the Islamic economic framework.

\section{Method}

This article is a library research and is therefore qualitative. In order to conduct the study, we survey some websites of scientific works database to find relevant articles on excessive behavior. These websites are:

1. Emerald Insight (www.emeraldinsight.com)

2. SAGE journal (www.journals.sagepub.com)

3. Science Direct (www.sciencedirect.com)

4. JSTOR (www.jstor.org)

5. Google scholar (https://scholar.google.com)

On these websites, some keywords are used to identify relevant articles. Those keywords are: Islamic Consumer Behavior, Conspicuous Consumption, Ethical Consumption, Luxury Consumption, Islamic Consumption Morality and Consumer Behavior. Some criteria are set in order to limit the results of the search. The criteria includes literature that can be found and accessed on the above websites and those which specifically discuss the topics in a direct manner. Based on the search, 33 articles were listed as relevant. To ascertain the relevance of the topic, the rating system is used to represent the degree of relevance to the topics. The relevance is categorized based on following criteria. First, understanding the nexus of consumption in the Islamic worldview. Any article that falls within this category must contain a description of the philosophy of consumption, its scope and its goals. Second, an organized principle of consumer behavior in the Islamic worldview. Articles within this category must explain some aspect of consumer behavior in accordance with Islamic sources. In addition, content analysis is conducted to systemically unfold the nature of excessive behavior in accordance with the Islamic economic framework of discussions. 


\section{Consumption in the Islamic Economic Framework: An Overview}

The intuitive thinking and manifesting one's desire to please and maximize their satisfaction is human nature right to the roots. The nature of a human is consistently rational and self-interested in order to achieve optimum pleasure; this is known as homo economicus, which was first introduce by John Stuart Mill in the $19^{\text {th }}$ century. The discussion on how the self-maximization progress of homo economicus is encounter by the existence of homo islamicus. Homo islamicus is assumed to be a part of an idealized society, embedded with Islamic values and commitment, which is distinctive from homo economicus (Farooq, 2011, p. 52). The debate of homo economicus and homo islamicus is at the insemination of spiritual or Islamic values in economic activities. One thing that is highlighted in these human natures, is that homo economicus realizes the potential of humans by immersing what has been provided around them and often or even negate the spiritual values which hold their desires. Homo islamicus is the ideal human that consider all spiritual aspects in their actions. This kind of normative issues that emerged in economic activities affect one another in their economic behavior. However, Farooq (2011) emphasizes that homo islamicus is based on the norms of Islam and seeks the existence of human beings, which has a strong transformative role. Furthermore, according to Asutay (2007), there are points of difference between homo economicus and homo islamicus, which is the maximization of utility between homo economicus and homo islamicus is distinguished based on the dimensional of utility-perceived. The dual dimension proposed in the Islamic views pertains to the present and hereafter satisfies individual well-being. However, in respect of the universally applicable theory of human economic behavior, the homo economicus and homo islamicus are one and the same, which is in accordance with the Quran (Maurer, 2012). Despite the different perspectives of homo islamicus and homo economicus in addressing the objective of man, Siddiqi (1992) interprets the main objective of Islam under the consumption framework as:

1. Every individual should consume enough economic goods to lead an efficient life.

2. Certain (prohibited) goods should be consumed.

3. Consumption of economic goods must not be extravagant just as excessive indulgence in luxurious living is discouraged.

4. Consumption of economic goods and the consequent satisfaction must not be the ultimate objective of individuals. It should serve as a means to the achievement of the higher ends of a purposive life.

Islamic consumer behavior is part of the ethical conduct of consumer behavior theory, which is inseminated by the Islamic values as its core elements. Hassan (1996) sets out three premises as redefining the development of Islamic consumer behavior:

1. A consumer will be assumed to decide what and how to consume in order to fulfil his needs and the needs of his dependents as this is his immediate responsibility.

2. In line with tawhid, a consumer is assumed to consider the welfare of his fellowmen and other creations of Allah from his consumption activity.

3. A consumer will be assumed to always consider consumption as an activity that can lead to the achievement of falāh. This in fact is a rational behavior.

Underpinning the difference in the philosophical foothold, a Muslim individual has no other alternatives to ideally understand the consumption behavior of Muslims rather than reviewing the real concept of Islamic consumer behavior. Adnan (2011) proposes that the Islamic worldview should be considered as the fundamental approach of consumption. As most of the studies on consumption often mention that the individual under Islam influences holds the idea of "should act this way", this means as a part of transformation attempt to act beyond what has been prescribed. The integration of Islamic values into the body of economic theory may not work, because the Islamic worldview of the individual is yet to develop 
into their vision of work. The embodiment of the Islamic worldview in the Islamic economic framework refers to the concept of tawhid, which touches the priority of the relationship between man and Allah, and also man-man relationships.

\section{Excessive Behavior (israf): An Underdeveloped Discussion}

As a part of study of consumer behavior, the study of excessive behavior is rarely found in any academic database and requires further inquiry. The most relevant topic was introduced in the $19^{\text {th }}$ century by Thorstein Veblen who discusses conspicuous consumption. The term "conspicuous consumption: refers to flashy consumption by consumers in order to demonstrate superiority to society and this discussion further develops into various studies such as hedonism, materialism, luxury consumption, etc. Wherein discussion by Muslim scholars focus primarily on conceptual levels which briefly elaborate on excessive behavior. The most recent study conducted by Furqani (2017) unfolds the principles of Islamic consumption: (i) the principle of permissibility; (ii) the principle of responsibility; (iii) the principle of balance; and (iv) the principle of priority.

According to these principles, the avoidance of israf practice specifically falls into the principle of balance; it is argued that the practice of israf could lead to inefficiency of resources and unequal distribution. Previously, Siddiqi (1992) argued that consumers operating under the Islamic spirit are strictly forbidden to indulge in luxuries, because the nature of luxury consumption would exercise deep influence on the individual's demand; this is known as conspicuous consumption in contemporary society. Furthermore, Kahf (1992) claims that consumption that does not adhere to consumption ethics leads to overconsumption, which is a characteristic of a Godless society. Hence, it may be surmised that Muslim scholars agreed that the practice of israf is condemned and should be avoided at all cost.

However, the development of studies that simply cover the general idea of israf as part of consumer ethical code of conduct derived from Islamic sources, may enable a specific discussion of israf as excessive behavior. The latest study specifically concerning the area of excessive behavior is conducted by Emari (2015), which uncovers a strong relationship between lifestyle and Islamic consumption patterns, specifically to segmenting the consumer market by observing the Muslim consumer demography. That study analyzed Islamic consumption patterns and categorizes them into 3 groups, namely: miserly consumption, moderate consumption, and prodigally consumption. Additionally, Ghassan (2015) emphasizes that the consumption system in Islamic economics contains a large number of consumption spending models between two thresholds. These latter indicates a minimum of spending that does not descend below the avarice threshold and a maximum of spending that does not exceed the excessiveness threshold.

The Western understanding of excessive behavior is part of the big framework of ethical consumption, thus, the study of conspicuous consumption is explored. According to Veblen (2005), conspicuous consumption is defined as overspending with the intent of displaying one's wealth and status, which relates to what has been addressed by Siddiqi (1992). Keynes agrees that the behavior of a consumer has a degenerative sickness known as myopia (short-sightedness) and prodigality, which together represent a standard explanation for over-consumption and for consumption tracking (current) income (D'Orlando \& Sanfilippo, 2010). In general, conspicuous consumption falls into the category of unethical consumption, which strongly suggests the principle of self-interest and the maximization of satisfaction. Brun and Castelli (2013) claim that the idea of luxury has been transformed over time which reveals its multifaceted nature. Thus, a comprehensive approach to classify luxury consumers is used first of all to reveal different customer profiles and to prove that the tangible/intangible and personal/social distinctions are relevant to an understanding of the motivations underlying the purchase of luxury products.

The willingness and ability to pay for luxury brands which negates the ethical values on consumption. Interestingly, Hudders and Pandelaere (2012) found that materialistic consumers are more inclined to consume luxury goods than less materialistic consumers. He believed that luxury consumption leads to enhanced positive mood, diminished negative mood and increased satisfaction with life, whereas the impact 
on negative and positive mood is not moderated by materialism, the impact of luxury consumption on satisfaction with life is more pronounced for materialistic consumers than for less materialistic consumers.

Materialistic consumers not only engage with luxury consumption more than less materialistic consumers, but they also derive more benefit from it (at least in the short run). These findings correspond with research by Lopes et. al. (2016) which states that hedonic happiness is a temporary happiness in the short-term . However, if hedonic consumption is considered as unethical consumption, then it should be assumed that hedonic consumption will cause social friction among those who have the ability to afford the goods (luxury or excessively) (Roper et. al., 2013). Furthermore, Ali and Wisniesk (2010) stress that where consumerism is considered as an ideology that celebrates consumption and spending, a society with limited productive capacity may consider this a threat to future development and may become more dependent on imports and foreign markets.

In this way, the luxury brands are often associated with hedonistic behavior. Although the consumer has been identified to the extends of particular profile, it cannot be generalized plainly to describe the various types of society in different parts of the world. This study neglects the role of religion as the boundary agent of conduct. Stillman et. al., (2012) found that, in the middle of conflict between material and immaterial consumers, high levels of spiritual awareness may reduce desires to consume material goods in a conspicuous manner.

\section{Understanding the Position of Excessive Behavior (israf) in the Islamic Economic Framework}

\subsection{The Origin of Excessive Behavior (israf) in the Islamic Framework}

Etymologically, excessive behavior (isrāf - سرف (! سرف) is derived from the Arabic roots of (sa-ra-fa) that means to exceed all bounds, be immoderate, be extravagant (Cowan, 1976, p. 408) and to neglect the act of

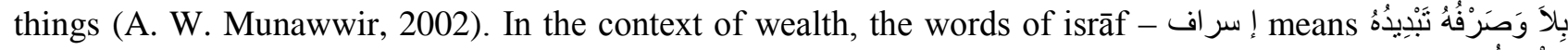

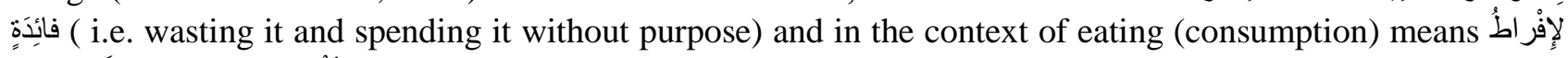
(i.e. excessive eating: indeed, excessive eating is evil and terrible). In conclusion, excessive behavior (israf) is defined as behavior that exceeds the limits in spending with no purpose, which leads to ignorance. Under this definition, excessive behavior is strongly associated to consumer spending activities. In the current Islamic economic discussion, consumption is viewed as a noble activity which contributes to the well-being of mankind (Furqani, 2017). Generally, the Quran has revealed an instruction to man to consume what has been provided by Allah, however the instruction is also followed by a set of principles. The most general revelations are recorded in surah Al-Maidah (5), verse 88:

"And eat of what Allah has provided for you [which is] lawful and good. And fear Allah, in whom you are believers."

This verse directly instructs man to consume what has been given by Allah under the permissibility principle, which abides to the Islamic laws that translate into halal (lawful) or haram (unlawful) consumption. Another revelation about consumption is recorded in surah Al-A'rāf (7) verse 31 as a fair warning of misconduct consumptions:

"O children of Adam, take your adornment at every masjid, and eat and drink, but be not excessive. Indeed, He likes not those who commit excess."

According to asbāb an-nuzūl, at that time, some Muslims travelled to Mecca to carry out Thawwaf in naked and forbade themselves to consume fat during pilgrimage. Hence, Allah reveals the instruction to have no excessive inclination towards lawful and unlawful. Since this verse convenes Muslim's daily activities such as praying, consumption is the proxy of human basic necessities that should be accomplished. The term 
of excessiveness which is introduced in the verse displaying the ethical code of conduct in every activity, which is vital to human life; the ethical boundary of avoidance of excessiveness has become a proper tool to limit human desires. When humans manage their desires in accordance with their necessities, this results in moderation.

\subsection{Needs, Consumption and Satisfaction of Excessive Behavior}

In order to identify excessive behavior in Muslim consumer activities, Muslim consumers ought to understand the distinction between wants and needs. According to Khan (2013, p. 5), need is the motivation of all human activities; the urge for a human being comes from inside the body as well as from outside (from family, society, religion etc.). The relationship between needs and the decision-making process of a consumer is important, because at a certain point, consumers may confronted by several dilemmas (Khan, 2013, p. 6). First, consumers have instinctive impulses forcing him to desire several things which may not be in accordance with their needs because they are not in line with the objective of his life. Second, consumers have to meet certain needs for which they may not have any psychological desires or instinctive impulses, but for which he is required to meet to improve his well-being and to achieve the objective of his life. Third, consumers are social animals that abide by social rules, norms and ethics; consumers have certain needs that must be met as a part of social behavior, even if they does not perceive them to be their needs.

Consequently, to elucidate the consumer dilemmas, Islamic teachings categorize consumption levels to describe the definition of needs in three categories: dharuriyat (five necessities), hajiyyat (convenience), tahsiniyat (refinement). These categories corresponds to work by Ibnu Qayyim which classifies consumption into three levels: (i) necessity; (ii) sufficiency; (iii) excessive, which is developed from hadith narrated by Tirmidzi No. 2380:

"Imam Ahmad said, had told us Abul Mugirah, had told us Sulaiman ibn Salim Al-Kalbi, had told us Yahya ibn Jabir At-Tai; he had heard Al-Miqdam ibn Ma'di Kariba Al-Kindi told him that he had heard the Prophet. said: There is not a container filled with Adam's son who is more evil than his stomach. It is enough for Adam's son to eat some food to raise up his sulbus bones. And if he is forced to do it, then one third for his food, one third for his drink, and a third for his breath."

In order to identify the practice of excessive behavior in Muslim consumption, the level of consumption is analyzed with respect to satisfaction as described in the figure below.

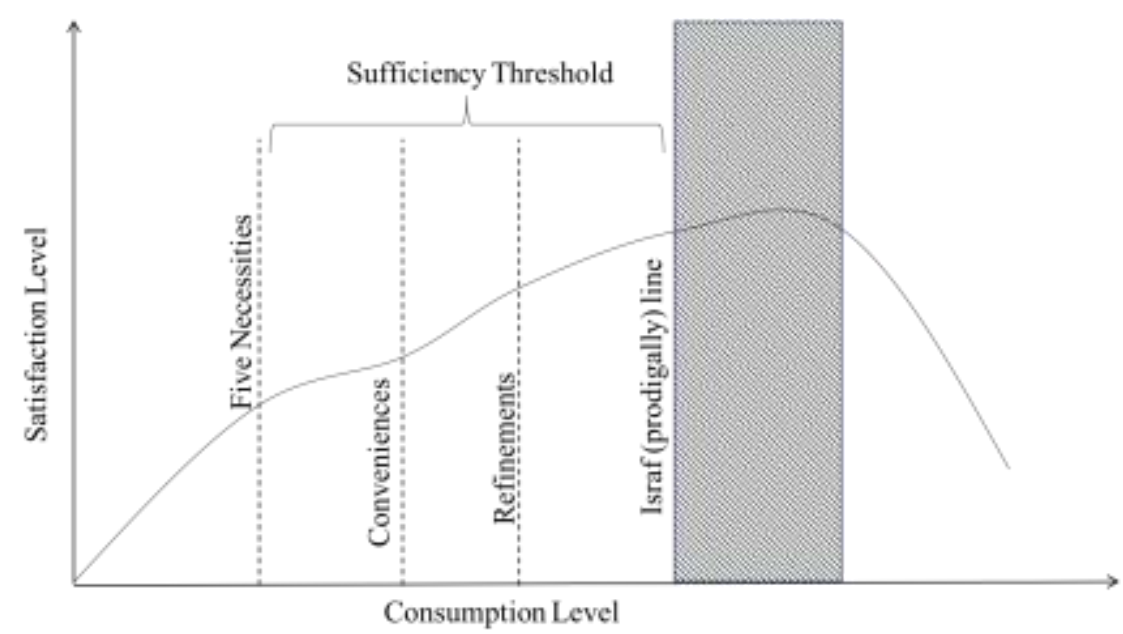

Figure 1. Relationship of satisfaction and consumption levels 
The figure above shows the relationship between consumption levels and satisfaction levels. The construction of this graphic is based on the principle of consumption under the Islamic morality framework which is emphasized by Furqani (2017), which is developed from Zarqa (1992). This consumption level represents the principle of priority under the hierarchy of "needs" that has been elaborated from the maqasidh al-shariah and categorised into three levels: (i) dharuriyat; (ii) hajiyyat; (iii) tahsiniyyat.

The first level of consumption refers to the maintenance of the five necessities which fall under the hierarchy category of dharuriyat (necessities). The five necessities that should be maintained in accordance with the concept of maqasidh al-sharia, which is preservation of faith, life, intellect, posterity, and wealth. This level of consumption must be maintained to avoid destruction of humanity. These five necessities are the first barrier of defence to save man from infidelity. Anas bin Malik narrates that Rasulullah PBUH said that "almost of poverty will become infidelity" (Imam Thabrani in mu'jamul ausath, 4/225, No. 4044).

This hadith teaches one about caution in consumption, although some scholars state this hadith is categorized as weak hadith. The meaning of this hadith is to remind society that poverty is not bad and reprehensible. Furthermore, Imam Al-Ghazali explains that poverty leads to infidelity because poverty causes people to incite the rich. Poverty may also encourage people to submit to something that may corrupt his honour and repudiate Allah's provision as part of Allah's trials, even to despise Allah's sustenance.

The second level of consumption is convenience consumption, which is a complementary consumption that facilitates the quality of an individual's life. The third level is refinement consumption, which is an embellishment consumption that improves an individual's quality of life further into perfection. However, these two levels of consumption should be maintained under the israf (excessive) line. According to Zarqa (1992), conveniences and refinements may be achieved optimally as long as they fall under the sufficiency threshold. He explains that the sufficiency threshold aims to make a person, (i) unlikely to depend on others financially, or better still, able to offer some assistance to others; (ii) able to remain content with his consumption and be thankful of Allah; and (iii) able to provide a "sufficiency threshold" for one's dependents. Although these levels may be obtained optimally, they also have the potential to increase excessive behavior practices.

In modern economics, the objective of consumption is to seek out and maximize consumer satisfaction. Although some Muslim scholars refuse to agree with modern economics, Siddiqi (1992) intercedes that the term "satisfaction" is not altogether devoid of the meaning of utilitarianism. According to him, the concept of satisfaction does not refer to any particular of satisfaction, whether it is spiritual, material, or otherwise. In fact, Furqani (2017) also discusses "wants-satisfaction". He explain that in the Islamic economics framework, wants-satisfaction is not considered as a basic economic problem because wants-satisfaction is not certain in term of goals and hence such effort is not only timeless but is also meaningless. The term "satisfaction" connotes the negative idea of consumption that implies selfishness and greed. However, the pursuit of economic progress is not a vice to Islam, in fact, it is considered as one of its' virtues when it is balanced and intended for a good cause (Kahf, 1992, p. 63). This teaches Muslim's to balance the orientation of life in this world and hereafter properly, which is mentioned in the Quran surah Al-Qasash verse 77:

"But seek, through that which Allah has given you, the home of the Hereafter; and [yet], do not forget your share of the world. And do good as Allah has done good to you. And desire not corruption in the land. Indeed, Allah does not like corrupters."

In conclusion, the term "satisfaction" is used to determine the Muslim consumer goals of consumption, however, the nature of satisfaction in this part consists of two dimensions: self-satisfaction (i.e. physical or material satisfaction can be perceived by consumer by optimizing the means to consume), and God's seeking satisfaction (i.e. spiritual satisfaction that perceived by believing that consumer has consume according to the Allah's provision and seeking Allah's grace). Spiritual satisfaction is uncommon in modern economics and corresponds to the concept of mardhatillah which was first introduced by Adnan (2011). 
Furthermore, the relationship between satisfaction and consumption levels in the previous figure addresses the issue of excessive behavior in the consumption theoretical framework. Based on the figure above, it is assumed that the increasing level of consumption is followed by an increasing level of satisfaction that is perceived by the consumer. Under this assumption, a Muslim consumer exhibits an increasing quality of life. The role of israf (prodigality) is to ensure that the consumer does not cross the sufficiency threshold. The violation of that limit is a contravention of the Islamic moral consumption principle, which includes the principle of permissibility, principle of balance, and principle of priority. The violation of the principle of permissibility is not limited to the substance level. In the framework of excessive behavior, the consumer tends to consume more than they need under particular conditions, such as an increase in income, discounts, big sales, etc. This causes a change to the status quo.

Since the practice of excessive behavior is driven by uncontrolled and unreasonable desire, the level of income and consumer availability to spend their wealth also contributes to practices that will lead to overconsumption. Kahf (1992) forewarns that the act of overconsumption in the Godless-society is condemned by Islam, which is known as israf (extravagance) or tabdhir (profligacy). According to him, these types of spending habits have become almost phenomenal in a consumer-oriented society. He defines extravagance as the overspending on lawful matters such as food, clothes, shelter, or even charity. Additionally, he mentions that this argument is given to the miserly rich man for not giving the poor their share, which is revealed in surah Yasin, verse 47:

"And when it is said to them, "Spend from that which Allah has provided for you," those who disbelieve say to those who believe, "Should we feed one whom, if Allah had willed, He would have fed? You are not but in clear error."

However, excessive behavior is not limited to basic goods as long as it does not contradict with lawful matters. In the previous figure, the assumption that the israf line also covers the sufficiency threshold of consumption, in the manner of spending beyond the need of conveniences and refinements level. To the extent that excessive behavior can be used to describe the level of satisfaction, it is known that when consumers spend more than the sufficiency threshold, their level of satisfaction increases exponentially. However, Lopes et. al. (2016) states that such happiness or satisfaction is only temporary. Thus, when the consumer is willing to add more consumption beyond the assuming excessive behavior, their satisfaction level will not increase, in fact, it will remain at the same level and will gradually decline at some point (which is proven the assumption of diminishing marginal utility in the modern economics theory).

\section{Conclusion}

Consumption is one of the noble activities included in the Quran as the manifestation of ibadah that organizes wealth. The practical level of spending in the form of consumption has been instructed under several principles. One of those principles is the avoidance of israf (excessiveness). The practice of excessive behavior is not a new issue. Many studies have attempted to construct consumer behavior under the Islamic worldview. In early studies, it was concluded that there are several principles that should be abided by the consumer, including: the principle of permissibility, the principle of responsibility, the principle of balance, and the principle of priority.

Muslim scholars agree that the nature of excessive behavior is condemned and considered unethical by Islam. Excessive behavior is defined as behavior that exceeds the limit of spending with no purpose, leading to the ignorance of society. The extent of excessive behavior is not limited to certain levels of consumption. The Muslim consumer may be unaware that they are engaging in excessive behavior when they are under the influence of a particular setting, where the pleasure of their practice is felt temporarily. The long-term effect of excessive behavior is enslaved by impulsive spending which causes a person to become ignorant to society. 
The limitations of previous research are one of the main factors in elaborating the discussion related to this topic. Hence, a more forward assessment incorporating contemporary elements on this topic is needed. In addition, further research should also directly examine similar practices in theories and applications in modern economics, which are analyzed in depth within the Islamic worldview.

\section{References}

Adnan, A. A. (2011). Islamic Consumer Behavior (ICB): Its Why and What. International Journal of Business and Social Science, 2(21), 157-165.

Asutay, M. (2007). Conceptualisation of the Second Solution in Overcoming the Social Failure of Islamic Banking and Finance : Examining the Overpowering of Homo Islamicus. IIUM Journal of Economics and Management 15, 15(2), $167-195$.

Azid, T., \& Asutay, M. (2007). Does ethico-moral coalition complement to economic coalition? A Response in the periphery of Islamic economics. Humanomics, 23(3), 153-173. https://doi.org/10.1108/08288660710779380

Brun, A., \& Castelli, C. (2013). The nature of luxury: a consumer perspective. International Journal of Retail \& Distribution Management, 41(11/12), 823-847. https://doi.org/10.1108/IJRDM-01-2013-0006

Cowan, J. M. (1976). Arabic - English Dictionary: The Hans Wehr Dictionary of Modern Written Arabic (3rd Editio). New York: Spoken Language Services, Inc.

D'Orlando, F., \& Sanfilippo, E. (2010). Behavioral foundations for the Keynesian consumption function. Journal of Economic Psychology, 31(6), 1035-1046. https://doi.org/10.1016/j.joep.2010.09.004

Emari, H. (2015). Prodigality in Islamic lifestyle: a new scale development. Journal of Islamic Marketing, 6(2), 188208. https://doi.org/10.1108/JIMA-08-2013-0064

Farooq, M. O. (2011). Self-Interest, Homo Islamicus and Some Behavioral Assumptions in Islamic Economics and Finance. International Journal of Excellence in Islamic Banking and Finance, 1(1), 52-79. Retrieved from http://papers.ssrn.com/abstract=1740729\%5Cnhttp://papers.ssrn.com/sol3/papers.cfm?abstract_id=1740729

Furqani, H. (2017). Consumption and morality: Principles and behavioral framework in Islamic economics. Journal of King Abdulaziz University, Islamic Economics, 30(Specialissue), 89-102. https://doi.org/10.4197/Islec.30-SI.6

Ghassan, H. B. (2015). Islamic Consumer Model, Fairness Behavior and Asymptotic Utility. Munich Personal RePEc Archive. Retrieved from https://mpra.ub.uni-muenchen.de/67141/

Hassan, N. M. H. N. (1996). Consumer Behaviour Theory from Islamic Perspective. IKIM Journal, 4(1), 49-62. Retrieved from IIUM Islamic Economic Collection Doc No. 4603

Hossain, B. (2014). Economic Rationalism and Consumption : Islamic Perspective. International Journal of Economics, Finance and Management, 3(6), 273-281.

Khan, F. (2013). An Alternative Approach to Analysis of Consumer Behaviour : Need for Distinctive Islamic Theory. Journal of Islamic Business and Management, 3(2), 1-35. https://doi.org/10.12816/0004996

Lopes, M. P., da Palma, P. J., Garcia, B. C., \& Gomes, C. (2016). Training for happiness: the impacts of different positive exercises on hedonism and eudaemonia. SpringerPlus, 5(1), 744. https://doi.org/10.1186/s40064-016-2407-y

Maurer, B. (2012). Re-formatting the economy: Islamic banking and finance in world politics. In Islam in World Politics (pp. 54-66). London: Routledge. https://doi.org/10.4324/9780203356920

Munawwir, A. W. (2002). Kamus Al-Munawwir Arab-Indonesia Terlengkap. (Z. A. Munawwir \& A. Ma’shum, Eds.) (2nd ed.). Surabaya: Pustaka Progresif.

Stillman, T. F., Fincham, F. D., Vohs, K. D., Lambert, N. M., \& Phillips, C. A. (2012). The material and immaterial in conflict: Spirituality reduces conspicuous consumption. Journal of Economic Psychology, 33(1), 1-7. https://doi.org/10.1016/j.joep.2011.08.012

Tahir, S., Ghazali, A., \& Syed Agil, S. O. (1992). Reading in Microeconomics - An Islamic Perspective. (S. Tahir, A. Ghazali, \& S. O. Syed Agil, Eds.). Malaysia: Longman Malaysia.

Veblen, T. (2005). Conspicuous Consumption. London: Penguin Books. 